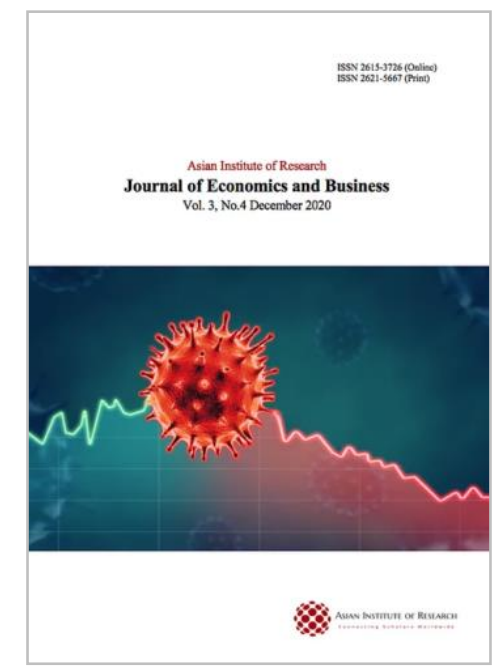

\title{
Journal of Economics and Business
}

Yuliawati, Dian, Kanto, Dwi Sunu, Bross, Noverdi. (2020), Can Digital Technology Really Contributes to Purchase Power? The Case of Digital Hospitality Application by Finnet Indonesia Corp. In: Journal of Economics and Business, Vol.3, No.4, 1645-1653.

ISSN 2615-3726

DOI: 10.31014/aior.1992.03.04.310

The online version of this article can be found at: https://www.asianinstituteofresearch.org/

Published by:

The Asian Institute of Research

The Journal of Economics and Business is an Open Access publication. It may be read, copied, and distributed free of charge according to the conditions of the Creative Commons Attribution 4.0 International license.

The Asian Institute of Research Journal of Economics and Business is a peer-reviewed International Journal. The journal covers scholarly articles in the fields of Economics and Business, which includes, but not limited to, Business Economics (Micro and Macro), Finance, Management, Marketing, Business Law, Entrepreneurship, Behavioral and Health Economics, Government Taxation and Regulations, Financial Markets, International Economics, Investment, and Economic Development. As the journal is Open Access, it ensures high visibility and the increase of citations for all research articles published. The Journal of Economics and Business aims to facilitate scholarly work on recent theoretical and practical aspects of Economics and Business. 


\title{
Can Digital Technology Really Contributes to Purchase Power? The Case of Digital Hospitality Application by Finnet Indonesia Corp
}

\author{
Dian Yuliawati ${ }^{1}$, Dwi Sunu Kanto ${ }^{1}$, Noverdi Bross ${ }^{1}$ \\ ${ }^{1}$ Postgraduate School of Management, Trilogi University, Jakarta, Indonesia \\ Correspondence: Dian Yuliawati, Postgraduate School of Management, Trilogi University, Jakarta, Pancoran, \\ 12760, Indonesia. Tel: +62811888954. E-mail: dianyuulia@ gmail.com
}

\begin{abstract}
Every producer always tries to achieve the goals and objectives through the products they produce. The resulting product can be sold or purchased by the end consumer at a price level that provides long-term corporate profits. It is in this framework that each producer must think about marketing its products, long before the product is produced until the product is consumed by the end consumer. This study aims to find out the effect of Brand Image and Price on the Purchasing Power of Property which is mediated by Digital Technology. This study used 91 respondents who were tenants of the Premium Cluster Apartments who used digital technology applications. This study uses Brand Image and Price as independent variables, Digital Technology as a mediating variable, and Purchasing Power as the dependent variable. Data obtained using a questionnaire and processed and analyzed using path analysis techniques. The results show that Brand Image has a positive and significant effect on Digital Technology, Price has a positive and significant effect on Digital Technology, Digital Technology has a significant effect on Purchasing Power, Brand Image has a positive and significant effect on Purchasing Power, Price has a significant effect on Purchasing Power, Digital Technology has a significant positive effect on mediating between Brand Image on Purchasing Power, Digital Technology mediates between Price and Purchasing Power.
\end{abstract}

Keywords: Brand Image, Digital Technology, Purchasing Power, Price.

\section{Introduction}

\subsection{Introduction}

Every producer always tries to achieve the goals and objectives through the products they produce. The resulting product can be sold or purchased by the end consumer at a price level that provides long-term corporate profits. Through the products it can sell, the company can guarantee its life or maintain the stability of its business and develop. It is in this framework that each producer must think about the marketing management activities of its product, long before this product is produced until the product is consumed by the end consumer. 
Marketing management is the process of analyzing, planning, organizing, and managing programs that include conceptualization, pricing, promotion and distribution of products, services and ideas designed to create and maintain beneficial exchanges with target markets to achieve company goals (Suparyanto \& Rosad 2015). Then Marketing Management can also be defined as the activity of analyzing, planning, implementing, and controlling programs designed to form, build and maintain profits from exchanges through target markets in order to achieve organizational (company) goals in the long term (Saidani \& Ramadhan 2013). Meanwhile, according to Kotler (2005), Marketing Management is referred to as the process of planning and implementing, thinking, pricing promotion, and channeling ideas for goods and services to create exchanges that meet individual goals in the organization. So it can be concluded that Marketing Management is an overall system of business activities aimed at planning, pricing, promoting, and distributing goods and services that satisfy the needs of both existing and potential buyers, and is the result of the work performance of business activities related to flow of goods and services from producers to consumers until the buying process occurs.

This study focuses on the analysis of one of the Telkom Group incubation products represented by Finnet Indonesia Corp., which discusses digital technology service solutions with the Finpay Invoice product brand as a digital technology factor, mediating the variable brand image and price that affects the purchasing power of property which some people use as profitable long-term stock investments. Specifically, the product being analyzed is one of the products of Telekomunikasi Indonesia Corp., namely Digihos (Digital Hospitality) and Finnet Indonesia as a subsidiary of Telkom was appointed to complete the Digital payment system, launched in mid-2017, this product was created as a digital payment technology solution for the property industry for the Apartment \& Premium Cluster Segments nationally.

Finpay Invoice service is a digital technology application prepared for the needs of the property sector for the Apartment \& Premium Cluster Segments as a payment tool for apartment electricity management fees that are used by managers (building management) and property owners (tenants) as a means of digital payment (online). But the use of the Digihos application is not optimal as can be seen in the following table.

Table 1: Target and Actual Achievements of each Digihos Operational Area

\begin{tabular}{llll}
\hline \multirow{2}{*}{ Operasional Area } & Target & \multicolumn{2}{l}{ Q1 2020 } \\
\cline { 3 - 4 } & & Actual & \% \\
\hline Sumatra Island & 387.897 & 104.732 & $27 \%$ \\
\hline Jakarta, Bogor, Tangerang, Banten & 820.453 & 287.159 & $35 \%$ \\
\hline West Java & 155.255 & 100.916 & $65 \%$ \\
\hline Central Java & 101.325 & 67.888 & $67 \%$ \\
\hline East Java & 376.128 & 263.290 & $70 \%$ \\
\hline Kalimantan & 124.100 & 69.496 & $56 \%$ \\
\hline Sulawesi & 97.837 & 36.200 & $37 \%$ \\
\hline Total Nasional & $\mathbf{2 . 0 6 2 . 9 9 5}$ & $\mathbf{9 2 9 . 6 8 1}$ & $\mathbf{4 5 \%}$ \\
\hline
\end{tabular}

Sales Marketing report data of Finnet Indonesia can be seen in the table above, Growth Metric Acquisition shows the insignificant growth in achievement during the first quarter of 2020 . Only $45 \%$ of the potential $100 \%$ occupancy target of more than 2 million Apartments and Premium Clusters. Achievement penetration level nationally. Sales Achievement deficiency is calculated based on the potential for residential development.

Digital Payment is moving dynamically towards Digital services with various segments and other changes as a result of developments and is a change in human habits in conducting financial transactions and payments, the existence of payment banking will decrease, the role of payment counters and banking branch offices will gradually be replaced by electronics banking such as text banking, mobile banking, internet banking and payment counters will be replaced by mobile payments or mobile channels. When viewed in terms of efficiency and time effectiveness, people prefer to use digital transactions. In the future, Bank customers will no longer need to come 
to the bank. All transactions can be done in your hand, transact safely, anywhere and anytime using a mobile phone.

Digital technology is growing rapidly, increasing global competition and the dynamics of market tastes, causing the ability to survive for companies is important so that they can compete in the market and avoid unfair competition (Colgate, 1998). Companies have the opportunity to succeed by creating new products or risk failing in business (Cooper \& Kleinschmidt, 2000). New product development is essential to achieving growth and success for any company. This is a critical factor, especially in high-tech industries, such as the telecommunications industry, where technological changes are constant (Barczak, 1994). Meanwhile, a good new product performance will maintain the company's survival (Cooper \& Kleinschmidt, 2000).

Calantone (1993) argues that not all products can be successful in the market. In the American market the product success rate is $54 \%$, then $60 \%$ in the Japanese market and 55\% in the UK market. Every 100 projects developed, 63 of which failed then 37 were launched, of which 25 were successful and 12 failed in marketing (Cooper \& Kleinschmidt, 2000). This phenomenon can also be seen in the marketing of the Digihos application, where achievement is only $45 \%$ of the 2020 target. This is closely related to consumer behavior in general.

Purchasing power (willingness to buy) is part of the behavioral component in the attitude of consumption. According to Kinnear \& Taylor (1995), purchasing power is the stage of consumers' tendency to act before buying decisions are actually implemented. Purchasing power can also be defined as the possible pattern of buyers who intend to buy a product (Doods, Monroe and Grewal: 1991). According to Keller (1998), consumer purchasing power is how likely it is that consumers buy a brand or how likely it is that consumers buy a brand or how likely it is that consumers move from one brand to another. Meanwhile, Mittal et al., (1999) found that the function of consumer interest is product quality and service quality. So Assael (1989) and Cobb-Walgren (1995) say that the purchasing power caused by the attractiveness of the product or service being offered is a mentality for consumers to reflect on the plan to purchase a product for a particular brand. In addition, Boyd \& Mason (1999) also argues that an increase in the attractiveness of a product that has been determined can increase the level of consumption. In general, consumer purchasing decisions take place in several stages, as follows.

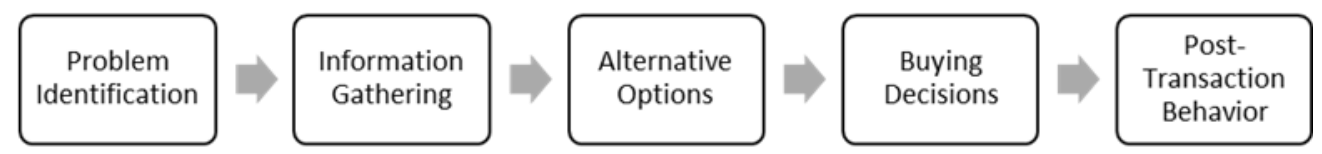

Figure 1. Steps of Buying Process in Consumer Behavior

The buying process begins when the buyer senses a difference between his real state and the desired state. The satisfaction it gets is the main source of information that consumers will seek out afterward purchasing decisions. After that comes an alternative assessment of the selected product. A consumer who will carry out his desire to buy something will make five types of purchasing decisions, including decisions about brands, prices, decisions about quantities, decisions about when to buy and decisions about how to pay. After purchasing a product, consumers will experience a level of satisfaction or consumer dissatisfaction with a product that will influence subsequent behavior. Consumers will also take actions after purchasing and use these products that get marketing attention. Marketing tasks do not end when the product is purchased but continue until the period after purchase (Kotler \& Armstrong, 2001).

In addition, price is one of the consumer factors in determining purchasing decisions on products where the price is the amount of money charged for a product or service, or the amount of value exchanged by consumers for the benefits of owning or using the product or service (Kotler \& Armstrong: 2001). Purchasing property as an offer of profitable long-term stock investment is inseparable from the brand image factor of the product where brand is a name, term, sign, symbol, or design, or a combination of these which are intended to identify the product or service of one or a group of sellers and distinguish it from other products (Kotler \& Armstrong, 2001). The desire to buy 
from customers is influenced by the perception of the product or it is called the Brand Image itself, research conducted by Moorman (1995) shows that the function of behavioral intention or consumer interest is a function of the quality of the product or service, so consumers will be more interested in the product. Based on the results, the higher the quality of a product, the higher the purchasing power of the product.

\subsection{Prior Studies}

There are several previous studies, one of which is research which aims to analyze the factors that influence quality and satisfaction in purchasing intention to consumers in the area studied. The problem has been identified that refilling consumer purchases is still low (Sulistyo, 2017). Then further research by Ghanimata \& Kamal (2012) shows that Price, Product Quality, and Location have a positive and significant effect on purchasing decisions where location has a very large influence compared to price and product quality. Furthermore, research by Walukow et al., (2014) states that Product Quality, Price, Promotion has a positive and significant effect simultaneously on consumer purchasing decisions, but partially location does not affect consumer purchasing decisions. In addition, there is previous research by Dewa (2009) which shows that the model is quite good. And the variables of product quality, promotional attractiveness and price show a positive and significant influence on purchasing power.

\subsection{Hypothesis Development}

Brand image is what consumers think and feel when they hear or see a brand. Image, in line with technological developments better known as the Internet of Things, companies will find it easier to provide the information needed by consumers to build a positive image. Digitization allows digital processes to encourage stronger opportunities to transform and change business capital, so it is concluded that the influence of digital technology on the brand image of a product has an important role in the success of business mechanisms to be accepted by consumers, so digitization (conversion), digital (process) and transformation digital (effect) accelerates and illuminates what is already there and is taking place horizontally and the processes of global change in society (Khan, 2016; Collin et al., 2015).

$\mathrm{H}_{1}$ : Brand Image has a positive effect on Digital Technology.

Digital technology has at least brought about tremendous changes in terms of connectivity, divergence, identity, knowledge, and business and trade, one of which is the property sector and the price of a product packaged in digital technology facilitates access to information received by consumers, so that the company makes it easier to monitor the price set by competitors so that the price determined by the company is not too high or vice versa, so that the price offered can lead to consumer desire to make a purchase.

\section{$\mathrm{H}_{2}$ : Price has a positive effect on Digital Technology.}

Purchasing decisions are a problem-solving approach to human activities to buy goods or services in fulfilling their wants and needs which consists of recognizing needs and wants, searching for information, it can be concluded that there is a positive relationship between Digital technology is stronger when new business models are packaged using digital technology so that creating a positive image is considered a strong stimulus for consumers to decide on a purchase.

$\mathrm{H}_{3}$ : Digital Technology has a positive effect on Purchase Power.

Brand image is the consumer's perception of the company or its product. With the brand image of the company for the products produced by the company, it is hoped that it can cause consumers' desire to make purchases.

\section{$\mathrm{H}_{4}$ : Brand Image has a positive effect on Purchase Power.}

Cheap or high price of a product is very relative. To say this it is necessary to compare it with the price of a similar product that is produced or sold by another company. Companies need to monitor the prices set by competitors so that the prices set by the company are not too high or vice versa, so that the price offered can lead to consumers' desire to make purchases. Price will influence purchasing decisions if the price of a product is in accordance with quality, affordable, and in accordance with its benefits. 
$\mathrm{H}_{5}$ : Price has a positive effect on Purchase Power.

Consumers make purchases of a product after understanding and being interested in what is offered, digital technology is a means for consumers to get information on a product to convey the Brand Image that has been built.

$\mathrm{H}_{6}$ : Brand Image has a positive effect on Purchasing Power mediated by digital technology.

Digital technology is a worldwide method of exchanging information and communicating through a network of connected computer cloud servers). Internet marketing (internet marketing) is marketing that uses Internet technology as a channel for delivering message content to many people simultaneously and instantaneously within a certain period of time.

$\mathrm{H}_{7}$ : Price has a positive effect on Purchasing Power mediated by Digital Technology.

\section{Method}

This research uses a quantitative approach. The quantitative approach emphasizes meaning, reasoning, the definition of a particular situation (in a certain context), examines more things related to everyday life. A qualitative approach, emphasizes the process compared to the final result, therefore the sequence of activities can vary depending on the conditions and the number of symptoms found. Research objectives are usually related to things that are practical. This study uses primary data, which is data collected by researchers directly from its main source, this data collection uses a questionnaire given to 91 respondents. This study uses Brand Image and Price as independent variables, then Digital Technology as the mediating variable, and Purchasing Power as the dependent variable.

\subsection{Research Design}

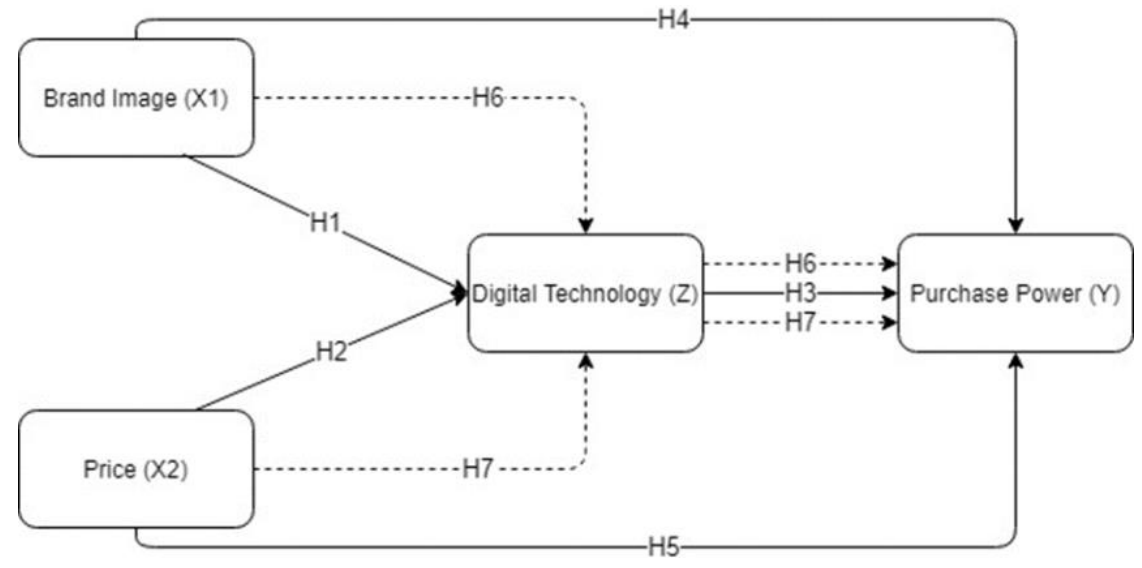

Figure 2. Research Framework

From figure above, the hypothesis 6 and 7 goes through Digital Technology, where in next segment of this study, will be calculated the indirect impact from both independent variables to dependent variable. Figure 2 also represent structural flow of the equation that will be divided further into two separate sub-structure.

\subsection{Path Analysis}

This analysis is used in examining the magnitude of the contribution shown by the path coefficient on each path diagram of the causal relationship between independent variables on moderation and its impact on the dependent variable. Path analysis is a technique for estimating the effect of the independent variable on the dependent variable from a set of observed correlations, providing a pattern of causal relationships between variables. This path analysis technique will be used in testing the amount of contribution (contribution) shown by the path coefficient on each path diagram of the causal relationship between the independent variable on moderation and its impact on the dependent variable. Correlation and regression analysis which is the basis for calculating the path coefficient. 
There are three stages in conducting path analysis, namely formulating hypotheses and structural equations, calculating the path coefficient based on the regression coefficient, calculating the path coefficient individually.

\section{Results}

\subsection{Sub-structure I Test}

The sub-structure test 1 consists of Brand Image, Price, and Digital Technology. Where the following are the results of data processing for sub-structure testing I.

Table 1. Model Summary of Sub-structure I

\begin{tabular}{lllllll}
\hline \multirow{2}{*}{ Variables } & \multicolumn{2}{l}{$\begin{array}{l}\text { Unstandardized } \\
\text { Coefficients }\end{array}$} & $\begin{array}{l}\text { Standardized } \\
\text { Coefficients }\end{array}$ & t-value & p-value & R-square \\
\cline { 2 - 6 } & beta & $\begin{array}{l}\text { Std. } \\
\text { Error }\end{array}$ & beta & & \\
\hline Constants & 1,684 & 0,169 & & 10,019 & 0,000 & 0,401 \\
\hline Brand Image & 0,272 & 0,046 & 0,482 & 5,877 & 0,000 \\
\hline Price & 0,169 & 0,047 & 0,297 & 3,619 & 0,000 \\
\hline
\end{tabular}

From table 1 above it could be seen that Brand Image and Price, both have direct and significant impact to Digital Technology by their p-value of 0.000 and 0.000 , respectively. Digital Technology is influenced by Brand Image and Price simultaneously by $40 \%$ based on the R-square value, and the remaining $60 \%$ is influenced by other factors. Every increase in Brand Image by one point, it will influence Digital Technology by 0.272, and vice versa. Every increase in Price by one point, it will also influence Digital Technology by 0.169 , and vice versa.

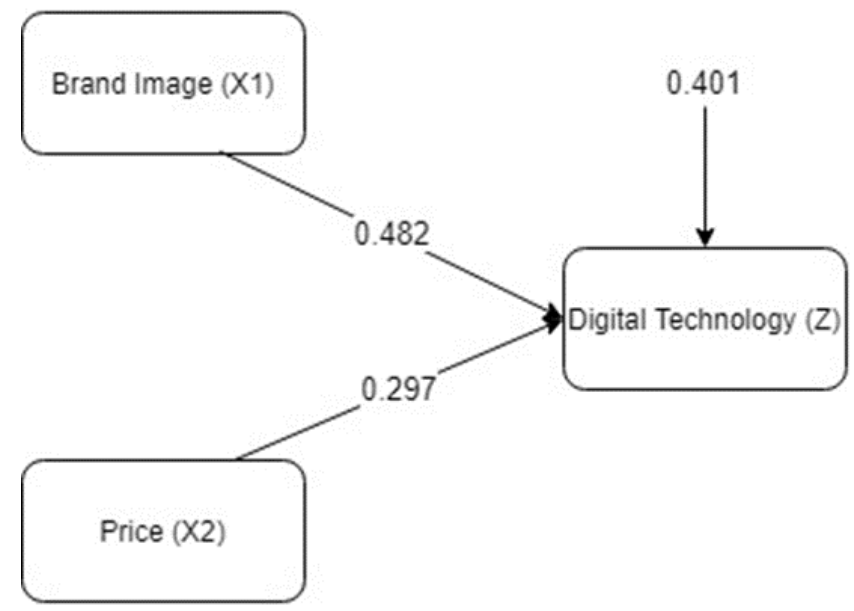

Figure 2. Sub-structure I Framework

Figure 2 shows the complete structural framework for sub-structure I equation. It can be seen on figure 2 as Brand Image and Price have standardized coefficient of 0.482 and 0.297 , respectively to Digital Technology. And path coefficient of $0.774(\sqrt{ }(1-0.401))$. Therefore, the structural equation of sub-structure I testing is as follow:

$\mathrm{Z}=0.482 \mathrm{X}_{1}+0.297 \mathrm{X}_{2}+0.774 \varepsilon_{1}$

\subsection{Sub-structure II Test}

The second sub-structure test consists of the Purchasing Power, Brand Image, Price, and Digital Technology variables. Where the following are the results of data processing for sub-structure testing II. 
Table 2. Model Summary of Sub-structure II

\begin{tabular}{|c|c|c|c|c|c|c|}
\hline \multirow{2}{*}{ Variables } & \multicolumn{2}{|c|}{$\begin{array}{l}\text { Unstandardized } \\
\text { Coefficients } \\
\end{array}$} & \multirow{2}{*}{$\begin{array}{l}\text { Standardized } \\
\text { Coefficients } \\
\text { beta }\end{array}$} & \multirow{2}{*}{ t-value } & \multirow{2}{*}{ p-value } & \multirow{2}{*}{$\mathrm{R}$-square } \\
\hline & beta & $\begin{array}{l}\text { Std. } \\
\text { Error }\end{array}$ & & & & \\
\hline Constants & 0,770 & 0,236 & & 3,266 & 0,002 & 0,540 \\
\hline Brand Image & 0,180 & 0,053 & 0,286 & 3,400 & 0,001 & \\
\hline Price & 0,170 & 0,049 & 0,266 & 3,466 & 0,001 & \\
\hline Digital Technology & 0,415 & 0,100 & 0,372 & 4,159 & 0,000 & \\
\hline
\end{tabular}

From table 2 above it can be seen that Brand Image, Price, and Digital Technology have direct and significant impact to Purchasing Power by their p-value of 0.001, 0.001, and 0,000 respectively. Purchasing Power is influenced by three factors as follow, Brand Image, Price, and Digital Technology simultaneously by $54 \%$ and the remaining $46 \%$ is influenced by other factors. Every increase in Brand Image by one point, it will influence Purchasing Power by 0.180, and vice versa. Every increase in Price by one point, it will influence Purchasing Power by 0.170 , and vice versa. Every increase in Digital Technology by one point, it will influence Purchasing Power by 0.415 , and vice versa.

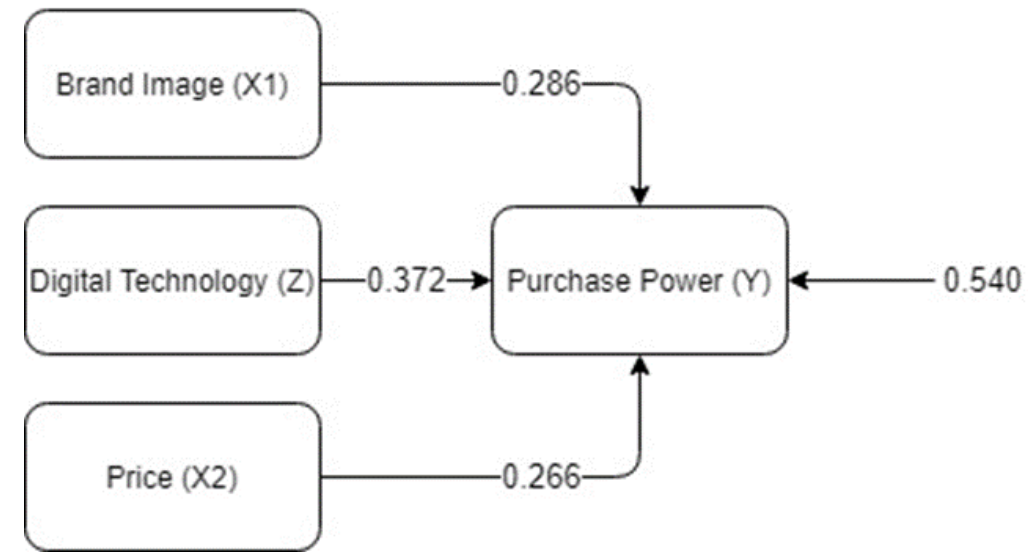

Figure 3. Sub-structure II Framework

Figure 3 shows the complete structural framework for sub-structure II equation. It can be seen on figure 3 as Brand Image, Price, and Digital Technology have standardized coefficient of $0.286,0.266$, and 0.372 , respectively to Purchasing Power. And path coefficient of $0.678(\sqrt{ }(1-0.540))$. Therefore, the structural equation of sub-structure II testing is as follow:

$\mathrm{Y}=0.286 \mathrm{X}_{1}+0.266 \mathrm{X}_{2}+0.372 \mathrm{Z}+0.678 \varepsilon_{2}$

\subsection{Indirect Impact and Total Impact}

If the two structural models are combined, there will be an indirect impact of $0.179(0.482 \times 0.372)$ and total impact of $0.465(0.286+0.179)$ experienced by the Brand Image on Purchasing Power through Digital Technology. There is also an indirect impact of $0.110(0.297 \times 0.372)$ and total impact of $0.376(0.266+0.179)$ experienced by the Price on Purchasing Power through Digital Technology.

\section{Discussion}

Brand Image (X1) has a positive and significant effect on Digital Technology (Digihos) (Y). The Apartment Premium Cluster which has been developed using digital technology (Digihos) owned by Finnet Indonesia Corporation, which provides convenience and creates various lifestyle changes so as to provide Product Quality, Service Quality, and Brand Image is well received by the public and feels satisfied with the products they have, so that Customer Satisfaction is created which is one of the main keys of success in business. When consumers 
are satisfied with a product that is sold by the company, the next hope that the company wants is to grow Customer Loyalty, which is the most difficult part of the business world. According to Tjiptono \& Chandra (2012), customer loyalty is a re-purchase of a certain product or brand that is the same over and over again.

Price (X2) has a positive and significant effect on Digital Technology (Y) at the Apartment Premium Cluster. There is an increase in the use of technology services that create convenience, especially for young people (millennials), so that the effect of price variables is significant on technology development in determining market strategies and prices to be set by companies so that they can compete with competitors

Digital Technology (Y) has a significant effect on Purchasing Power (Z). According to Grabner-Krauter \& Kaluscha (2003) shopping via the internet has its own uniqueness compared to traditional shopping, namely in terms of uncertainty, anonymity, minimal control and potential in taking opportunities. With access to information on products being sold, buyers need not be afraid to make transactions through certain application platforms.

Brand Image (X1) has a positive and significant effect on Purchasing Power (Z). Where this states that a seller who has a high brand image will generate interest in buying from consumers.

Price (X2) has a significant effect on Purchasing Power (Z). This means that if the customer has a good perception of the price and service received by the customer as expected, then the customer will make a repeat purchase.

Digital Technology (Y) has a significant positive effect on mediating between Brand Image (X1) and Purchasing Power (Z). The results of the study state that the recommended brand image through technology will have an impact on purchasing power, especially in the consumer market, where there are direct and indirect effects of digital technology as a means of information media that can provide convenience and knowledge about products where consumers can be solicited by simply accessing digital information needed and easily understood by market consumers.

Digital Technology (Y) mediates between Price (X1) and Purchasing Power (Z). The ease of obtaining information through digital media technology is one of the keys to the success of a product brand image, reaching the consumer market. Meanwhile, there is a management principle that the ease of obtaining product information and the strategy for reducing profits applies to higher quality, because the number of buyers who are willing to pay for higher quality is decreasing. So that the company should not rush to the conclusion that the company needs to design the highest quality. Thus it can be concluded that price, ease of access to product information and product quality have a relationship with Purchasing Power.

\section{Conclusion}

Brand Image has a positive and significant effect on Digital Technology. Price has a positive and significant effect on Digital Technology. Digital technology has a significant effect on purchasing power. Brand Image has a positive and significant effect on Purchasing Power. Price has a significant effect on Purchasing Power. Digital technology has a significant positive effect on mediating between Brand Image and Purchasing Power. Digital technology mediates between Price and Purchasing Power.

\section{Acknowledgments}

The author of this study would like to thank two supervisors Dwi Sunu Kanto, Ph.D and Noverdi Bross, Ph.D for providing guidance and input during the preparation of this study. 


\section{References}

Assael, H. (1989). Consumer Behavior and Marketing Action (6 ${ }^{\text {th }}$ Ed). New York: International Thomson Publishing.

Barczak, G. (1994). Gaining Superior Performance of New Products in the Telecommunications Industry. Journal of Business \& Industrial Marketing, 9 (4), 19-32.

Boyd, T. C., \& Mason, C. H. (1999). The Link between Attractiveness of "Extrabrand" Attributes and the Adoption of Innovations. Journal of the Academy of Marketing Science, 27 (3), 306-319. https://doi.org/10.1177\%2F0092070399273002

Calantone, R. J., Benedetto, C. A. D., \& Divine, R. (1993). Organizational, Technical and Marketing Antecedents for Successful New Product Development. R\&D Management, 23 (4), 337-351. https://doi.org/10.1111/j.1467-9310.1993.tb00839.x

Cobb-Walgren, C. J., Ruble, C. A., \& Donthu, N. (1995). Brand Equity, Brand Preference, and Purchase Intent. Journal of Advertising, 24 (3), 25-40. https://doi.org/10.1080/00913367.1995.10673481

Colgate, M. (1998). Creating Sustainable Competitive Advantage through Marketing Information System Technology: A Triangulation Methodology within The Banking Industry. International Journal of Bank Marketing, 16 (2), 80-89.

Collin, J., Hiekkanen, K., Korhonen, J. J., Helen, M., Itala, T., \& Helenius, M. (2015). IT Leadership in Transition - The Impact of Digitalization on Finnish Organization. Department of Computer Science, Aalto University (pp. 1-121). Espoo, Finland.

Cooper, R. G., \& Kleinschmidt, E. J. (2000). New Product Performance: What Distinguishes the Star Products. Australian Journal of Management, 25 (1), 17-46.

Dewa, N. K. (2009). Analysis of The Influence of Product Quality, Promotion Attraction and Price on Buying Interest (StarOne Case Study in Central Jakarta Area) (unpublished master's thesis). School of Postgraduate, Diponegoro University, Semarang.

Dodds, W. B., Monroe, K. B., \& Grewal, D. (1991). Effects of Price, Brand, and Store Information on Buyer's Product Evaluations. Journal of Marketing Research, 28 (3), 307-319.

Ghanimata, F., \& Kamal, M. (2012). Analysis of The Influence of Price, Product Quality, And Location on Purchase Decisions (Study on Milkfish Product Buyers Juwana Elrina Semarang). Diponegoro Journal of Management, 1 (2), 1-10. http://ejournal-s1.undip.ac.id/index.php/djom

Grabner-Krauter, S., \& Kaluscha, E. A. (2003). Empirical Research in On-line Trust: A Review and Critical Assessment. International Journal of Human-Computer Studies, 58 (6), 783-812. http://10.1016/S10715819(03)00043-0

Keller, K. L. (1998). Strategic Brand Management: Building, Measuring, and Managing Brand Equity. New

Jersey: Prentice-Hall, Inc.

Khan, S. (2016). Leadership in The Digital Age - A Study on The Effects of Digitalization on Top Management Leadership (unpublished master's thesis). Faculty of Social Sciences, Stockholm Business School, Sweden.

Kinnear, T. C., \& Taylor, J. R. (1995). Marketing Research: An Applied Approach. New York: McGraw Hill.

Kotler, P. (2005). Marketing Management (11 ${ }^{\text {th }}$ Ed). Canada: Prentice Hall.

Kotler, P., \& Armstrong, G. (2001). Principles of Marketing. Canada: Prentice Hall.

Mittal, V., Kumar, P., \& Tsiros, M. (1999). Attribute-Level Performance, Satisfaction, and Behavioral Intentions Over Time: A Consumption System Approach. Journal of Marketing, 63 (2), 88-101.

Moorman, C. (1995). Organizational Market Information Processes: Cultural Antecedents and New Product Outcomes. Journal of Marketing Research, 32 (3), 318-335. https://doi.org/10.2307/3151984

Saidani, B., \& Ramadhan, D. R. (2013). The Influence of Advertising and Product Attributes on Purchase Decision on The Samsung Galaxy Series Smartphone (Surveys on Samsung ITC Roxy Mas customers). Management Science Research Indonesian Journal, 4 (1), 53-73. http://journal.unj.ac.id/unj/index.php/jrmsi/article/view/778

Sulistyo, H. (2017). Relationship between Quality and Customer Satisfaction in Forming Consumer Purchase Intention: A Study on Four Service Industries in Semarang. Business Strategy Journal, 4 (1), 8-24. https://doi.org/10.14710/jbs.4.1.8-24

Suparyanto \& Rosad. (2015). Marketing Management in Media. Business and Management Research Journal, 6 (3), 241-258.

Tjiptono, F., \& Chandra, G. (2012). Service, Quality, Satisfaction. Jogjakarta: Andi Offset.

Walukow, A. L. P., Mananeke, L., \& Sepang, J. (2014). Influence of Product Quality, Price, Promotion, and Location on Consumer Purchase Decisions at Bentenan Center Sonder Minahasa. Journal of Economic, Management, Business and Accounting Research, 2 (3), 1737-1749.

https://doi.org/10.35794/emba.v2i3.5969 